\title{
ROBBED WATER, RAPED EARTH: WAGNER'S RING OF THE NIBELUNG AS NATURE WRITING
}

\author{
Tanya Perkins \\ Indiana University East, USA
}

\section{Abstract}

This article argues that composer Richard Wagner indirectly anticipates environmentalist Aldo Leopold's land ethic through his treatment of natural elements within the operatic cycle The Ring of the Nibelung. While the 19th century European perspective often viewed land through the lens of romantic anthropomorphism, Wagner presents environmental elements as members of what Leopold later defined as the "biotic community," with voice, legitimate interests and agency, resulting in a libretto open to interpretation as a form of nature writing. To explicate such an interpretation, this article examines Wagner's treatment of fire, earth and water in the light of Lawrence Buell's four criteria for environmental texts, as set out in The Environmental Imagination: the intertwining of human and natural history; recognition and validation of non-human interests; human accountability toward the environment; and acknowledgement of the environment as a process rather than a constant. Keywords: Wagner's The Ring of the Nibelung, Leopold's Land Ethic, "Biotic Community," Elements.

\section{AGUA ROBADA, TIERRA VIOLENTADA: EL ANILLO DEL NIBELUNGO \\ DE WAGNER COMO ESCRITURA DE LA NATURALEZA}

\section{RESUMEN}

Este artículo propugna que el compositor Richard Wagner anticipa de forma indirecta la ética de la tierra del ambientalista Aldo Leopold, a través del tratamiento de los elementos naturales en su ciclo operático El anillo del nibelungo. Mientras en el siglo XIx la perspectiva europea consideraba a menudo la tierra a través de la óptica del antropomorfismo romántico, Wagner nos presenta los elementos ambientales como parte de lo que Leopold posteriormente definió como la "comunidad biótica," dotada de voz, intereses legítimos y agencialidad, en un libreto abierto a la interpretación como una forma de escritura de la naturaleza. Para explicar tal interpretación, este artículo examina el tratamiento del fuego, la tierra y el agua de Wagner, siguiendo los pasos de los cuatro criterios para textos ambientales de Lawrence Buell (tal y como aparecen en The Environmental Imagination): entremezclar lo humano con la historia natural; el reconocimiento y la validación de los intereses no-humanos; la responsabilidad humana sobre el medioambiente; y la constatación del medioambiente como un proceso, más que como una constante.

Palabras clave: El anillo del nibelungo de Wagner, ética de la tierra de Leopold, "comunidad biótica," los elementos. 
Beginning in 1848, Richard Wagner set out to compose a universal musicdrama, or Gesamtkunstwerk, uniting poetry, drama, tragedy, and music in what he described as a revolutionary "true Art" (46), a total synthesis of theatrical elements. He drew on Norse myths - the epic poem Das Nibelungenlied, the Poetic Edda, Prose $E d d a$, and Volsunga saga, among others- modern European translations of which became popular in the early $19^{\text {th }}$ century, leading to a resurgence of interest in the gods and giants of Northern Europe as a source of artistic inspiration for writers and visual artists of the Romantic era (Lindow 37). What Wagner produced, 25 years later, was the four-opera series The Ring of the Nibelung, a mythic cycle encompassing themes of love, power, freedom, nature and more. However, it is Wagner's treatment of nature, specifically the depiction of natural elements as active members of a biotic community that will be the focus of this essay. Deryck Cooke observes that Wagner "saw nature as the ultimate reality, and human development as a power-struggle based on a crime against nature" (245). This awareness extends even to staging Grundulur Kreuzer describes Wagner's profuse use of water mist, steam, and flame, as part of his strategy (among other things) to capture nature's reality in a theatrical setting, particularly nature in its "uncorrupted" state (5). More significantly, Wagner portrays water, earth and fire as speaking presences with whom the gods' collective fate -and, by extension, our own- is bundled. In this respect, The Ring shares similarities with other environmental texts or even of nature writing although, at first glance, it might seem to fall well outside the boundaries of these genres.

Upon what basis might a libretto be considered nature writing? At the 1995 ASLE conference, John Elder defined nature writing as the "reflective essay grounded in attentiveness to the natural world" (quoted in Armbruster 2), while Cheryl Glotfelty, in her introduction to The Ecocriticism Reader, terms it "natureoriented nonfiction" (xxiii). Yet these narrow definitions overlook other kinds of nature-oriented writing that examine the linkage of human and non-human and the complexity of the "natural" and "cultural" ecotones surrounding us, and so fail to capture the chameleon quality of the genre. Although he, too, describes nature writing as "environmental nonfiction," Lawrence Buell admits that "nothing is more striking than its variegated character" (397). For example, Thoreau's Walden, while non-fiction, "flaunts its diversity, fragmenting into multigeneric collage," notes Buell, describing the genre during Thoreau's time as "more 'heteroglossic,' than that of the novel" (397). A more expansive definition of nature writing comes from Scott Russell Sanders who uses Emerson's phrase "[to] fasten words to visible things" as characteristic of those writers who situate their work within the context of a larger, non-human theater, with all of the consciousness and consequence that might imply (188).

Moreover, Karla Armbruster and Kathleen Wallace call on ecocriticism to "[expand] its boundaries...to address a wider spectrum of texts" (2). "Spectrum," with its sense of limitless variety along a continuum, is a more representative metaphor, according to Jean Arnold, who constructs the genre of nature writing as a gamut with empirical science writing at one end and poetry at the other, all of it bound together by a desire to "make sense of the human condition in the face of a mysterious nature" (22). She uses these words specifically in reference to Charles 
Darwin's Origin of Species, which blends features of such diverse genres as the novel, travelogue, personal journal and scientific treatise.

While Darwin's rhetorical purposes obviously differ from Wagner's, both of their genre-blurring works share an important feature: a depiction of the commonality between human and natural phenomenon. Darwin's strategy was the methodical observation and recording of species' life patterns, while Wagner deployed the power of myth, reworked through his own creative impulse, to reveal the consequences of violating nature in order to realize absolute political power. Cooke notes that for Wagner, myths were "humanity's intuitive expression, in symbolic form, of the ultimate truths about its own nature and destiny" (10). In both cases, the net effect is to invoke, as Buell says (in reference to Origin of Species), "something like an 'ecological' vision of human and natural history as parts of a single environment," describing, not the precise form of Darwin's work, but its effect on and for the reader (417). I would argue that the same may be said for Wagner's Ring, and it is precisely that vision -not merely of nature as an indifferent entity distinct from the human world, but the recasting of the human-nature relationship, the contemplation of an interconnected biotic community within which ethical action is incumbent upon human members toward other members- which lends his libretto the essence of nature writing.

In simplest terms, the plot of The Ring is thus: Wotan, king of the gods, rules by means of the laws and contracts inscribed on his spear, made from a branch torn from the World Ash Tree. One of those contracts is with the giants, Fafner and Fasolt, who agree to build Wotan a palace, Walhall, in exchange for the goddess Freia. Wotan instead gives them the Rhinegold -gold previously stolen by Alberich, the dwarf, from the Rhine and made into a magic ring. The problem is that Wotan, as enforcer of law, is obliged to return the stolen gold to the Rhine, not use it for his own purposes. Instead, he hands it over to the giants, setting off a chain of events that ultimately lead to the annihilation of the gods themselves. Attempting to avoid this, Wotan fathers Sigmund, who he hopes will be an independent hero able to steal back the ring. When Sigmund is revealed as unqualified, Wotan orders Brunhilde, his Valkyrie daughter, to let him die. Unable to save Sigmund, Brunhilde safeguards his wife, who gives birth to Siegfried. Wagner, in an 1854 letter to his friend August Röckel, describes Siegfried as "the final creative product of [Wotan's] supreme, self-destructive will... a fearless human being" (qtd. in Ashurst 233). Yet neither Siegfried nor Brunhilde can forestall what is not just a political destruction but an ecological one as well. Siegfried regains the ring of power, only to be murdered. It is Brunhilde that, at last, returns the ring to the Rhine, even as flames envelop Walhall, destroying the gods. One of the key revelations of The Ring is that the gods aren't independent of their environment, that their fate is connected to maintaining what Speight Jenkins calls the "fundamental order of the world" (14), an order that I would interpret as requiring recognition of natural elements as part of an interdependent biotic community.

In Norse mythology, fate is embodied in the three Norns, female deities corresponding to the three classical Fates, who weave, measure and cut the threads of destiny. Wagner departs from his source texts by limiting the Norns to uttering 
only what their mother, Erda, a name which means simply "Earth," reveals to them, and her knowledge is not absolute. For Wagner, ever the political revolutionary, fate did not necessarily predetermine or constrain action -"Fate is to be overcome," as Cooke says (231). It is inextricably linked to action, as can be seen from his comment in the same letter to Röckel referred to earlier: "[Wotan, king of the gods] rises to the tragic heights of willing his own destruction. This is all we need to learn from the history of mankind: to will what is necessary and to bring it about ourselves." (qtd. in Ashurst 233). Accordingly, Erda is unable to predict, finally, what the future will be for Wotan, only that everything will, in fact, end, an outcome put into motion by Wotan's action of breaking his own law and failing to return the gold to the Rhine (Cooke 230).

Wotan's failure in this regard reveals himself-though king of the gods-as both "timeless and completely human" (Jenkins 14), his "heroic locale" our own world, as Paul Acker and Carolyne Larrington suggest, despite the dwarves, norns and giants that happen to populate it (1). Examining The Ring as an eco-parable reveals that the gods are indivisible from their environment, their eventual destruction traceable to a failure to recognize their role within a Leopoldian biotic community. That recognition was violated by the theft of gold from the Rhine by the dwarf Alberich, a failure that Wotan, as enforcer of law, neglects to cure by returning the ring to the Rhine daughters who are its guardians and themselves voiced elements of nature. As an act of injustice to the river, this failure takes on environmental implications.

In his 1949 essay collection, $A$ Sand County Almanac, Aldo Leopold identifies what he considers to be human obligation to the land, water, air and other biotic resources, as the third and final stage in the evolution of an ethical paradigm. The first stage governs behavior between individuals, while the second defines obligations between individuals and society. The third stage extends society to include "soils, waters, plants and animals," recasting Homo sapiens as fellow citizens, rather than subjugators, of the land, with a concomitant limitation on acceptable actions (204). The land ethic does not assume stasis or Edenic harmony; change is inevitable as some species prevail and others go extinct. However, it recognizes that the consequences of human-induced disruptions are not always immediately discernible. An ecological conscience, therefore, operates as a "mode of guidance for meeting ecological situations... involving such deferred reactions" (203). It is noteworthy that theft of the Rhinegold did not bring about immediate ecological cataclysm. Much time passed before the effects manifested themselves in annihilation, and then only after repeated warnings by voiced natural elements-fire, water and earth. In this way, Wagner's libretto, with its characterization of nature as populated by living, speaking entities that one "ignores at one's peril" can be seen as a kind of template for Leopold's land ethic (Manes 15).

If, therefore, generic boundaries might not exclude The Ring from being experienced as a form of nature writing, how does the libretto function within that arena? To answer, I will examine how Wagner personifies water, fire and earth with voiced presences, activating them as speaking members of a biotic community rather than a silent backdrop against which androcentric action plays out. Christopher Manes points to animistic cultures that saw human speech as only one part of a 
larger, articulate world that included "the language of birds, the wind, earthworms, wolves, and waterfalls - a world of autonomous speakers" (15). In the West, this view was gradually displaced by rationalist discourse privileging speech as an "exclusively human prerogative" (15), effectively silencing non-human voices. The source material Wagner drew on in creating The Ring-collections of ancient myths, many of which pre-date the arrival of Christianity in Scandinavia- were amenable to reversal of such silencing. Although having human faces, the characters in those collections straddle physical and spiritual realms and shift forms from human to animal to element, finding common roots in Yggdrasill, the World Ash Tree, a massive tree that unites the three realms of the mythic universe-underworld, middle earth and heaven. This tree, from which Wotan created his spear, absorbs the pain of all creatures, the "tribulations of the universe at every level and suffer[ing] just as much as those who dwelled in it" (Littleton 277). Thus myth, for Wagner, weaves "porous boundaries" between human and non-human (Buell 417).

\section{FIRE}

A godlike spirit subdued by Wotan, Loge (or Loki) is identified in both the Prose Edda and the Poetic Edda as handsome but evil, punished by the gods for murdering Baldr, Odin's son. Characteristically, Wagner reconfigures the nature of Loge to suit his own plot, presenting him as not overtly evil, but capricious, unsteady as a flame in the wind, tamed around the edges only. According to Cooke, Wagner took the link to fire from Jacob Grimm, who identified Loki's genesis with "Logi the natural force of fire" in the form of a giant (qtd. in Cooke 172). Accordingly, Loge is not only the spirit of fire and trickery, notes Speight Jenkins, but "represents one of the four elements-fire, water, earth and air" (14), associated with the gods and yet clearly not one of them. "I'm not god-like," Loge confirms in Scene Two of Das Rhinegold (36). He helps Wotan at certain moments, taking the lead in stealing Alberich's gold to pay off the giants, coming when summoned, as when Wotan commands him to encircle the sleeping Brunhilde with flame and, later, to ignite the dead wood of the World Ash Tree in the ultimate conflagration. Yet, Loge retains independence: "I roam through the whole wide / world as I please" (27) he boasts to the gods. His recognition of Wotan's authority is partial at best, while Wotan, like a member nation of the nuclear club, deceives himself in thinking he has fire under control and that its use in achieving power has no consequences.

Particularly revealing is the dialogue between Loge, Wotan and the Rhine daughters at the end of Das Rhinegold. It is Loge who first reveals that a fundamental injustice has been perpetrated on the Rhine by the theft of its gold. He arranges for himself and Wotan to steal both the gold hoard Alberich has had his Nibelung slaves mine for him and the magic ring. It is the ring, specifically, that belongs to the Rhine, for it was made from gold that Alberich himself stole from the river at the opera's beginning. Loge repeatedly urges Wotan to give the gold to the giants as payment for Walhall, but to return the ring to the Rhine, where it rightfully belongs. Wagner here draws a distinction between the gold mined from the earth and that 
stolen from the river, even though Cooke describes both as symbolizing "the raw material of nature" (208). This distinction is Wagner's own doing, as is his originating the gold in Rhine as its home, although The Poetic Edda contains references to gold treasures being found in the vicinity of the Rhine or in a waterfall (Cord 190). The point is that the use of natural resources in and of itself is not problematic -the gold that Alberich mines is not cursed, notwithstanding his enslavement of his fellow dwarves. Rather, the curse lies upon the gold stolen from the Rhine, a resource crucial to the life of the ecosystem. Wagner describes its golden light diffusing throughout the whole river, representing, in essence, the very life of the river, but once the gold is taken, darkness soon spreads through the water. The curse comes upon those who misuse the gold to gain power, thus implicating themselves in the diminishment of natural elements -in this case, a riverine environment- from which usable resources originate in the first place. This is the critical wrong that has been perpetuated and which needs to be put right. Three-quarters of a century after The Ring's completion, Leopold articulated a parallel principle within the land ethic: "A thing is right when it tends to preserve the integrity, stability and beauty of the biotic community. It is wrong when it tends otherwise" (224-25).

Loge is the only one among the pantheon that recognizes the urgency of the situation, declaring: "[T] he Rhinemaidens / must have that gold / and to them Wotan will give it" (63). Instead of being a deceiver, as Loge is portrayed in the Eddas, Wagner very nearly makes him "the god of truth" (Cooke 353). As both law maker and enforcer, Wotan could not have been unaware of the imperative that the social order he himself created now imposed upon him. Accordingly, his crime in not returning the ring is worse than Alberich's theft of it in the first place, as Alberich points out:

If I have sinned,

I sinned but against myself;

But against all that was,

Is, and shall be,

You are planning a crime

By laying your hand on the ring! (57)

Yet the lure of limitless power is irresistible for Wotan, even if it comes at the expense of natural resources. It is only when yet another natural element, Erda, the earth goddess, rises in front of him and speaks that Wotan gives up the ring -even then, he does not return it to the Rhine, thus restoring ecological justice, but gives it to the giants as ransom to release Freia, whose golden apples preserve the gods' immortality.

At this point, watching the gods enter Walhall, Loge turns away in frustration at the short-sighted actions of the gods, uttering this prophecy:

Ashamed I'd be

to share in their dealings;

I feel a temptation

to turn and destroy them; 
change to flickering fire,

and burn those great ones

who thought I was tamed (70-71)

Cooke interprets Loge as representing Wotan's own power of creative intellect, the "flame" of genius, but also notes that this is a function of his "essential role of fire-spirit" (175). Yet Loge's words, particularly those spoken here, expose an ominous future, one that is difficult to understand as originating within Wotan himself, at least not at this point in the storyline. Rather than the voiced element of fire being merely a reflection of human impulses, Wagner gives it agency, distinct from and with interests sharply different than that of human society, here embodied in the gods. Thus Loge observes and denounces the self-absorption of the gods -of Wotan, in particular- who construe their actions as exempt from consequence and privilege their own political and social power at the expense of other members of the biotic community. Loge's words further reinforce Wagner's expression of fire as a natural element only thinly controlled, who serves human interests with more than a little unpredictability.

As the gods are making their way to Walhall, Wotan hears the voices of the Rhine daughters, begging for their gold. Angrily, he tells Loge to "stop their tiresome lament" (71). In response, Loge tells the Rhine daughters:

You in the water

stop wailing to us.

Hear what Wotan decrees.

Never more

will you see your gold;

let the gods' new golden splendor

shine upon you instead! (72)

This is not exactly what Wotan has just said but, as Sandra Corse points out, an ironic paraphrase meant to disparage Wotan's duplicity and highhandedness in his use of a resource to which he has no right (29). Loge alludes to the original effect of the gold when set in its rightful venue -beneath the Rhine's waves- where it diffuses the entirety of the water with a "golden splendor," underscoring its role in the overall vitality of the river rather than simply being an inert mass on the river floor (72). Now the Rhine's vigor is diminished and the Rhine daughters must make do with a land-based "splendor," which of course, is no splendor at all for the water-dwellers. It's analogous to a government official inviting indigenous hunter-gatherers to enjoy the florescent-lit aisles of a Walmart built where their forest once stood. About this exchange, Corse asserts that "Loge's use of Wotan's typical speech patterns here [conveyed musically through the adaptation and mixing of the leitmotivs] is a rhetorical stance he takes on in order to criticize Wotan... [to] signal his own distance" (29).

Although a consideration of music is beyond the scope of this essay, it is useful to briefly discuss Wagner's use of the leitmotif, a brief, reoccurring musical phrase that identifies each character, aptly suited in mood and tone to the character's 
nature or what he or she represents. Leitmotivs are the musical counterpart to the oral expressions of all characters -god, human, animal or natural element- signaling an active presence. Moreover, these leitmotivs were not merely repeated each time the character appeared on the stage, but were adapted and mixed with other motives to create multi-layered variations, depending on the action, so that the phrases are "more like [the characters'] own voices discovered than like invented melodies," as Elliott Gilbert remarks (68), weaving together and then breaking apart in a tapestry of sound and meaning. In the scene just discussed, when Loge discharges Wotan's words to the Rhine daughters, Corse describes how the leitmotif changes from the "quick, recitative style" associated with Loge to an "arioso style, filled with fourths and fifths, more typical of Wotan's lines." But, as she notes, "Loge adopts Wotanlike music only to mock it" (29).

\section{WATER}

As a second, voiced, non-human presence, the Rhine daughters have both habitat and history within the water, with names like lapping waves: Woglinde, Flosshilde, and Wellgunde. Both Robert Donington and Deryck Cooke suggest that they are symbolic of nature (Cooke 245) but I would argue that the symbolism functions on a finer level. Though called the "All-Father," Wotan is not identified within the libretto or Scandinavian mythic tradition as their father; instead, they tell Alberich the dwarf that they are appointed guardians of the gold by their father, the river: "Our father told us, / but then he warned us / we should guard it" (14). Still, confined to their riverine environment, the Rhine daughters are at a disadvantage. As both females and a natural resource, they are ripe for exploitation. If, as Vera Norwood suggests, "woman is to man as nature is to culture" (324), then the vignette played out in the opening scene of Das Rhinegold is one of both sexual as well as environmental politics, with unfulfilled desire as the recurrent theme and woman as symbol of fertile, beckoning land (or water, in this case).

The opera opens with the three Rhine daughters at play, darting about in the depths of the water as Alberich watches. When he makes fruitless efforts to catch first one, then another, they taunt him, remaining just beyond his grasp. Unable to capture even one of them, Alberich climbs to the top of a crag where he takes revenge by stealing the gold and cursing love forever. Relinquishing love is necessary in order to master the gold, as Woglinde tells the dwarf; the one who would use its power "must renounce / all joys of love" (15). In a general sense, her words primarily refer to romantic love. Within the context in which they are spoken, however, her words can also be understood to refer to the natural elements surrounding the dwarf, coming as they do toward the end of Scene 1, which concerns itself almost exclusively with Alberich's passionate yet fruitless pursuit of the Rhine daughters. The sole focus of Alberich's love in Scene 1, up until the moment when the gold is revealed, are the three Rhine daughters, embodying the natural element of water.

Alberich's pursuit of their elusive physical beauty suggests images of European explorers in search of a new Eden, a virgin wilderness rich in resources to be 
shipped home, promises of which lured them across the Atlantic to an "untouched" New World. Kolodny cites the example of Pocahontas's marriage to John Rolfe as a symbol for the "possibility of... actually possessing the charms inherent" in virgin nature (172) and yet actual possession proved as illusory as Alberich's momentary capture of Wellgunde. "You're tight in my grasp!" He says, to which she answers, "So tight, I slip from your hands," swimming away (9). It is only after the reality fails to live up to his desire in literally possessing one of the Rhine daughters that Alberich utters the curse on love and is then able to steal the gold. Thus one construction of nature is exchanged for another as two sides of a binary -nature as untouched, beckoning virgin, or nature as enemy meant only to be subdued and stripped of its resources. Similarly, for European explorers in search of a new Eden, America was soon found to be rugged and harsh, an awakening accompanied by revised depictions of native women as "hag-like, ugly and immoral," according to Kolodny (172). Both figurative and literal gold might be had in the form of abundant natural resources, but those European explorers and settlers who survived the hard reality of the New World environs initiated significant disruption of healthy ecosystems in the form of clear-cut forests, over-grazed prairie, drained marshes, and the near-extinction of native peoples.

Perpetration of injustice on a vulnerable minority is recurring theme in literature, but the innocent party here is the element water, given voice through the Rhine daughters, and it is violation of their legitimate interest in the gold that centers the plot. The gold has measurable effect on the quality of the water, diffusing a golden glow throughout the river. When the gold is stolen, it plunges the river into a literal darkness, as the Rhine daughters lament in Act 3 of Gotterdammerung:

Night lies in the waters:

They once were bright,

When through the waves

Our father's gold shone in its splendor. (306)

Environmental damage often occurs incrementally; some immediate effects may be detected, though the ultimate catastrophe may still lie in the future. "Legitimate interest" to use Buell's phrase (7) implies an interest based on rule of law; for the Rhine, it is a universal law that has been violated and so it is only natural that the Rhine daughters turn to Wotan for aid, as they do in Scene IV of Das Rhinegold.

As previously discussed, Wotan's rule of law is represented by his oathinscribed spear, but the question of justice goes deeper. This is because his spear is made from a branch torn from the World Ash tree that unites all realms of the mythic universe. That Wotan rules by means of contracts and treaties inscribed on that spear, implying an ordered rule of law, is significant in two ways: First, the creation of his spear leads to the withering of the tree, a plot point entirely of Wagner's creation, for although original Scandinavian lore has Yggdrasill's roots gnawed by serpents, it is only in The Ring that its deterioration begins with Wotan's use of a branch to institute his own law. Cooke states the following about the implications of both Alberich's theft of the Rhinegold, and Wotan's act of tearing a branch from 
the World Ash tree: "Absolute world-power can be achieved by ravishing the raw material of nature..." (148).

The second significance lies in the fact that, although the spear represents a systematic, hierarchical rule of law, it is itself based upon a much older system, one of a unified, holistic and shared ethic represented by the World Ash tree itself. Yggdrasill is a unifying paradigm for all life, absorbing and sharing the pain of all creatures, the "tribulations of the universe at every level and suffer[ing] just as much as those who dwelled in it" (Littleton 277). With this in mind, we can understand the Rhine daughters' petition for justice from Wotan as having a dual basis. As ruler and keeper of the formal, political system of law, Wotan had obligation to enforce the system that he himself had created. But even more fundamental was the foundation upon which Wotan's system rested -the community ethic bound up in Yggdrasill, the interconnectedness of all life in that mythic world, literally and figuratively interlacing itself through all realms and, by extension, binding all to each other.

Thus, the system of justice that Wotan was obliged to enforce extended to all parts of the biotic community, including water. It is worth noting that in Wagner's day, this mythical paradigm found scientific expression in Darwin's newly published Origin of Species, wherein a metaphorical Tree of Life is described, revealing the pattern of common descent that unifies all life in earth, linking life to the natural, inanimate elements from which it sprang, and lending biological support to Leopold's land ethic many decades later.

\section{EARTH}

Annette Kolodny considers America's most persistent and beloved myth to be the characterization of land as incessantly feminine, "land as woman," passive, receptive, conquerable (171). Although she applies this myth as explanatory of the "pastoral vocabulary" which burgeoned in the wake of the earliest white explorers to the New World, she acknowledges that this was nothing new (175). Something similar was going in Europe in the mid-19th century. Wagner loved to hike in the hills of Bavaria, and his environmental aesthetic manifests itself in his music, mimicking, for instance, rushing river waters during the opening bars of Das Rhinegold or a forest filled with birds in Siegfried, as Sternberg elaborates (345). But, consistent with Kolodny's observation, Wagner tended to feminize the natural world -Loge being an exception - as evinced in his creation of one of the most mysterious and enigmatic characters of The Ring cycle: Erda, the earth goddess.

Warren Darcy traces Wagner's conception of Erda to the Poetic Edda, which describes Odin's encounter with a Wala or wise woman who reveals that the death of Oden's son would precede the gods' annihilation (445). The name "Erda," which means simply "earth," was Wagner's own doing. Although in recent years, some scholars have expressed skepticism regarding the coherence of Erda's role within The Ring, viewing the text through an ecocritical lens relieves some of the ambiguity, particularly when examined in conjunction with Wotan's failure to deliver justice to the Rhine. Erda's ominous appearance serves notice on the gods that their ac- 
tions do, in fact, have consequence -that they have been found to be accountable for disruptions to the biotic community of which they are part.

Robert Frost may have wondered whether the world will end in fire or ice, but Erda's first appearance in Scene IV of Das Rhinegold makes one thing clear: it will end. "All things that are,/perish!" She cries, materializing out of seemingly nowhere and proceeding to warn Wotan to give up the ring, even though the die is already cast (65). Rather than immortality before him, Wotan learns that his time is finite. As Darcy explains, "Wotan can save himself from...everlasting damnation only by relinquishing the ring of power and atoning for his past behavior" (447).

With her ponderous and lugubrious persona, in comparison with which the gods seem flyweight, Erda is a reminder of the transitory nature of life which now, because of the ring's curse, even includes the gods. But she is still fundamentally woman and therefore conquerable, eventually succumbing to Wotan's sexual overtures, which he recounts in Act II, Scene II of Die Walkure: "By love's enchantment / I conquered the Wala, / humbled her silent pride" (107). His seduction of Erda is a futile attempt to wrest more information from her; the only result is the birth of his nine Valkyrie daughters. As in the case of the Rhine daughters, here is an echo of what Kolodny calls: the vocabulary of "feminine landscape" and of "destructive aggression" (177). Feminized land is "virgin," "subdued" or "conquered," each term being defined in relation to man's actions toward it. Feminized land construes environment as that which has been penetrated by a human presence, as in "to penetrate the wilderness," a phrase which, as David Mazel so aptly notes, "foregrounds male sexual agency" and explains the historical male human stance toward land and the objectification and commoditization of its inhabitants, whether wolf, buffalo or Blackfoot (140). This perspective has proven difficult to relinquish, as attested by Rebecca Pollard's April 2000 headline in the Boston Phoenix: "Big Oil Eyes Rape of Arctic Wilderness." Though rape is not limited by gender, the syntactic context of the headline conjures historically feminine connotations within an environmental drama.

Gotterdammerung opens with the three Norns, Erda's daughters, recounting how Wotan broke a branch from Yggdrasill and made his spear, inscribing his "holy laws and treaties" then using it to rule the world (249). However, the establishment of law as a vestige of human -or, in this case, divine- culture at the expense of a massive, living biosystem like the World Ash tree has consequences. "Death seized on the tree," the Norns recount, "whispering waters / then failed in the spring" that flowed at its base, a spring that, according to Norse mythology (though not mentioned in The Ring) Wotan had earlier drunk from in order to obtain both wisdom and poetry (248). He paid for the drink from the spring with the loss of an eye. Yet, the natural world paid far more heavily. Wotan centralized his power by his rule of law from his great fortress Walhall, but its cultural and physical framework was built upon the despoliation of natural elements. Directly or indirectly, Wotan dried up the spring of wisdom, killed the World Ash tree, raped the earth and stole from the river. His rap sheet reads like an indictment written by the Union of Concerned Scientists, his actions disturbingly analogous to those of modern industry, as witnessed by names like Chernobyl, the Exxon Valdez and the Three Gorges 
Dam. At the conclusion of The Ring, Wotan has the remains of the World Ash tree hacked down and the dry timber piled around the base of Walhall, within which he sits along with the other gods, drinking and brooding, awaiting a destruction he cannot now avoid. The detritus of his actions -the deadwood of the World Ash tree- literally kindle their consequences.

And it is inescapable. In the final scene of Gotterdammerung, Walhall is engulfed in flames. Concurrently, the Rhine overflows its banks, flooding the world and allowing the Rhine daughters to retrieve the ring of power from Brunhilde's corpse before its waters extinguish the inferno. Thus, it is the natural element of water that ultimately restores order to the universe, while the myopic gods go up in smoke. Water is both life-giving and cleansing; hence, the opening of the cycle's first opera, Das Rhinegold and the conclusion of the last, Gotterdammerung, are mirror images of each other. The Ring thus begins and ends with the Rhine, a reminder of how organic life has always ebbed and flowed in response to the movement of natural elements -floods, glaciations, asteroids, volcanoes and earthquakes.

In his introduction to The Environmental Imagination, Lawrence Buell quotes E.O. Wilson's warning: "No intellectual vice is more crippling than defiantly self-indulgent anthropocentrism" (5). Anthropocentrism has privileged human interests to the detriment of the non-human, paving meadows, eliminating species and replacing willow groves with big box retail space. The power of nature writing lies in its ability to illuminate the importance of meadows, mice and willow groves by letting us glimpse our common flesh and understand, as Buell would say, how porous that boundary between species really is. If, as Jean Arnold proposes, one of the distinguishing features of nature writing is to "imaginatively construct a wholeness of vision toward the natural world," then Wagner's Ring may, with its story of power and betrayal among common flesh, indeed find its place within the variegated spectrum that is nature writing (22). 


\section{WORKS CITED}

Acker, Paul and Carolyne Larrington (eds.): Introduction. Revisiting the Poetic Edda: Essays on

Old Norse Heroic Legend. New York: Routledge, 2013. Print.

Armbruster, Karla and Kathleen Wallace (eds.): Beyond Nature Writing: Expanding the Boundaries of Ecocriticism. Charlottesville: University Press of Virginia, 2001. Print.

Arnold, Jean: “From So Simple a Beginning:' Evolutionary Origins of US Nature Writing.” Interdisciplinary Studies in Literature and the Environment 10.1 (2003): 11-25. JSTOR. Web. 1 Oct. 2013.

Ashurst, David: "Wagner, Morris and the Sigurd Figure." Revisiting the Poetic Edda: Essays on Old Norse Heroic Legend. Eds. Paul Acker and Carolyne Larrington. New York: Routledge, 2013. Print.

Buell, Lawrence: The Environmental Imagination. Cambridge: The Belknap Press of Harvard University Press, 1995. Print.

BuEll, Lawrence: The Future of Environmental Criticism: Environmental Crisis and Literary Imagination. Malden: Blackwell Publishing, 2005. Print.

Cooke, Deryck: I Saw the World End. New York: Oxford University Press, 1979. Print.

Cord, William O.: The Teutonic Mythology of Richard Wagner's The Ring of the Nibelung, vol III, Part I. Lewiston: The Edwin Mellon Press, 1991. Print.

Corse, Sandra: “The Voice of Authority in Wagner's Ring." New Studies in Richard Wagner's The Ring of the Nibelung, Ed. Herbert Richardson. Lewiston: The Edwin Mellon Press, 1991. 19-37. Print.

DARCY, Warren: "Everything that is, ends!': The Genesis and Meaning of the Erda Episode in 'Das Rheingold”" The Musical Times. 129:1747 (1988): 443-447. JSTOR. Web. 25 Nov. 2009.

Donington, Robert: Wagner's "Ring” and its Symbols: the Music and the Myth. New York: St. Martin's Press, 1974. Print.

Gilbert, Elliott L.: "Wagnerian Musical Drama and English Literature." Journal of Aesthetic Education. 12.3 (1978): 65-72. JSTOR. Web. 15 Nov 2009.

Gitell, Seth: "Big Oil Eyes Rape of Arctic Wilderness." Boston Phoenix. 10 April 2000. Web. 6 Dec. 2009.

Glotfelty, Cheryl: Introduction. The Ecocriticism Reader. Eds. Cheryll Glotfelty and Harold Fromm. Athens: University of Georgia Press, 1996. xxxirI. Print.

Jenkins, Speight: “The Timelessness of the Ring.” Encore. Seattle Opera. 34.1: 14-16. Print.

Kreuzer, Gundula: “Wagner-Dampf: Steam in Der Ring des Nibelungen and Operatic Production.” The Opera Quarterly. 27. 2-3 (2011): 179-218.

Kolodny, Annette: “Unearthing Herstory.” The Ecocriticism Reader. Ed. Cheryll Glotfelty and Harold Fromm. Athens: University of Georgia Press, 1996. 170-181. Print.

Leopold, Aldo: A Sand County Almanac. New York: Oxford University Press, 1949. Print.

Lindow, John: Norse Mythology: A Guide to the Gods, Heroes, Rituals, and Beliefs. New York: Oxford University Press, 2002. Print.

Littleton, C. Scott (ed.): Mythology: The Illustrated Anthology of World Myth and Storytelling. San Diego: Thunder Bay Press, 2002. Print. 
Manes, Christopher: "Nature and Silence." The Ecocriticism Reader. Ed. Cheryll Glotfelty and Harold Fromm. Athens: University of Georgia Press, 1996. 15-29. Print.

Mazel, David: “American Literary Environmentalism as Domestic Orientalism”. The Ecocriticism Reader. Ed. Cheryll Glotfelty and Harold Fromm. Athens: University of Georgia Press, 1996. 137-146. Print.

Norwood, Vera L.: "Heroines of Nature." The Ecocriticism Reader. Ed. Cheryll Glotfelty and Harold Fromm. Athens: University of Georgia Press, 1996. 323-350. Print.

Pollard, Rebecca: “Big Oil Eyes Rape of Arctic Wilderness.” Boston Phoenix. 6-13 April 2000. Web.

SANDERs, Scott Russell: "Speaking a Word for Nature.” The Ecocriticism Reader. Ed. Cheryll Glotfelty and Harold Fromm. Athens: University of Georgia Press, 1996. 182-195. Print.

Sternberg, Rolf: "Fantasy, Geography, Wagner and Opera." Geographical Review. 88.3 (1998): 327-348. JSTOR. Web. 1 Sept. 2013.

WAgner, Richard: “Art and Revolution,” Trans. William Ashton Ellis. The Wagner Library. Web. 15 June 2013.

Wagner, Richard: The Ring of the Nibelung. Trans. Andrew Porter. New York: W.W. Norton \& Company, 1976. Print. 